\title{
Marking Practices and the Making of the Qin Terracotta Army
}

\author{
Xiuzhen Li, Andrew Bevan, Marcos Martinón-Torres, Yin Xia, Kun Zhao
}

Postprint from Journal of Anthropological Archaeology 42: 169-183

doi: 10.1016/j.jaa.2016.04.002

\section{Introduction}

A striking feature of Qin period material culture is the frequency with which it preserves stamped, incised or painted marks with a variety of Chinese characters, numerals or (as yet unintelligible) symbols (SIAATQ 1988; Yuan 1987; 1990; 2009; 2014). Contemporary written records, on bamboo slips and wooden boards, also confirm how central such marks were to the logistical organisation and legal apparatus of the Qin state (ca.475-221 BC, especially during the latter part) and later Qin Empire (221-206 BC; Bianxiezu 1981; 2001; Hulsewé 1985; Hunan Provincial Institute of Archaeology 2006; 2012). In a general sense, repeated mark-making was an administrative strategy that enabled Qin administrators to mobilise people, raw materials and finished goods in vast bulk, subject to careful quality and quantity control, and archaeologically, this strategy is nowhere more obvious than in the manufacturing feat constituted by Emperor Qin Shihuang's mausoleum and his Terracotta Army. This paper considers the production marks associated with both the terracotta figures in Pit 1 of the mausoleum (particularly the Terracotta Warriors) and their accompanying bronze weapons. We compare and contrast the marking practices on these two very different kinds of artefact, devoting close attention to what this implies about workshop organisation or the operational sequences behind their manufacture. We also assess the location of such signs on their parent objects as well as their wider spatial distribution across the pit as a whole, ultimately with a view to understanding craft organisation and project logistics during this crucial early phase of empire-building in China.

By craft organisation and project logistics, we mean those production sequences and wider bureaucratic procedures that lay behind the mausoleum project, and wish to undertand how they might also be indicative of Qin craft activity, military practice and state interference and in other situations as well. Related to this question are also issues such as the size, location, organisation and number of different craft workshops, how knowledge was shared within and between workshops, what efforts were made at standardisation or quality control, as well as when and why. There is of course a considerable anthropological and archaeological literature on these topics, especially with regard to specialisation and standardisation (e.g. Torrence 1986; Earle 1987; Costin 1991; Stark, 1991; Costin and Hagstrum 1995; Clark 1995; Eerkens and Bettinger, 2001; Roux 2003; Eerkens and Lipo, 2005; Sun 2008), including plenty of work on Chinese material culture (e.g. Bagley, 1995; Ledderose, 2000; Underhill, 2002; Li, 2007; Sun, 2008) and previous collaboration by the authors (Li 2012; Li et al., 2014; MartinónTorres et al., 2014). 
There is a vast array of surviving Qin palaeographic evidence that relates in interesting ways to the above topics. Many examples occur of both decipherable writing and undecipherable marks, and these are found on almost every possible material, including bronze, iron, stone, jade, bamboo, wood and clay. Likewise, it is clear that writing was being deployed for an extraordinarily broad range of purposes in the Qin period: emperor's edicts, juridical statutes, governmental ordinances, routine legal issues, religious texts, craft organisation, military affairs, political administration, public declarations, international diplomacy, historiography, private letters, and much else (Huang, 1980; Hunan Provincial Institute of Archaeology, 2006; 2012; Kern, 2000; Bianxiezu, 2001; Yuan, 2002; Yuan and Liu, 2009). More broadly, routine, highly organised and ubiquitous marking practices are salient features in many early complex societies (e.g. Egypt and Mesopotamia: Foxvog 1995; de Maaijer 2001; Wengrow 2008; Wagensonner 2009) are especially conspicuous across contemporary 1st millennium BC Eurasia form China to the Mediterranean (e.g. Hellenistic Greece and Rome: Harris ed. 1993; Blondé and Muller eds. 1998; Chaniotis 2005; Bachmann 2009), with in all cases intriguing combinations of text, numbers, pseudo-script and symbols linked to the various priorities of production, distribution and consumption (e.g. Andrássy et al. eds. 2009). However, the writing on the terracotta warriors and their weapons arguably constitutes an especial insightful case where we might devote attention to the content of the inscriptions, their material culture forms and their distributions in analyticallyinteresting ways.

Considerable palaeographic evidence is preserved on both (a) the terracotta soldiers of the Qin First Emperor and (b) the bronze weapons they carried. Despite a lot of interest in these marks (Yuan 1984; 1990; Huang, 1990; Li 2012; Li et al., 2011; 2012; 2014; Yuan and Liu, 2009), most treatments so far have placed their emphasis on how basic decipherment might complement the evidence for artisanal practice that is preserved in the documentary record. In contrast, there has been no systematic attention given to the spatial location of such marks, nor to comparison-and-contrast between the marks on the terracotta figures and those on the bronze weapons. This paper aims to revisit these marks with the above opportunities in mind, and reflects a wider collaborative effort combining metallurgical, chemical, quantitative and spatial analysis (e.g. Li 2012; Li et al., 2011; 2014; Martinón-Torres et al., 2011; 2014; Bevan et al., 2013; 2014) to investigate the nature of the craft logics and logistical efforts (a) underpinning Qin ceramic warrior and bronze weapon production, (b) underwriting the layout and construction of the mausoleum pits, and ultimately also arguably (c) contributing to the emergence and administration of the Qin empire itself (Figure 1).

$<$ Insert Figure 1 here $>>$

\section{Marks on the terracotta figures}

As part of the initial discovery of the First Emperor's tomb complex in 1970s (SIAATQ, 1988; Yuan, 1990), some 1087 terracotta soldiers were excavated in the front, easternmost portion of Pit 1 , and it is on this large, spatially coherent sample of warriors that this paper focuses. Across this group of 1087 warriors, there are 283 that bear marks: more precisely, 57 figures have stamped marks, 109 have incised names, 157 bear incised numbers, and one has a painted mark, with many examples of warriors 
exhibiting a combination of these (Table 1, but also Yuan 1990; Wang 1994: 568; Yuan and Liu 2009: 21). These marks include 4 different place-names, 66 different personal names (Appendix 1; with ongoing archaeology in other trenches producing a grand total of 87 names: Yuan 1990), and 92 names including that from other pits within the tomb complex (Yuan and Liu, 2009: 10), and 68 different numerical signs (Yuan 2014). Apart from three marks found on the terracotta horses (that match warrior codes 38, 50, and 66 in Appendix 1), most of the preserved characters and numbers were found on the terracotta warriors. Below we classify these marks further and consider their varying positions on the bodies of the terracotta figures, as well as how different marks are distributed across Pit 1.

\begin{tabular}{|l|l|l|l|l|}
\cline { 3 - 5 } \multicolumn{1}{c|}{} & \multirow{2}{*}{ Stamps } & \multicolumn{2}{|l|}{ Incised } & \multirow{2}{*}{ Painted } \\
\cline { 3 - 5 } \multicolumn{1}{c|}{} & & Textual & Numeric & \\
\hline Total Marks & 57 & 109 & 157 & 1 \\
\hline With personal names & 12 & 54 & & \\
\hline With place-names & & 4 & & \\
\hline Numerals & & & 68 & \\
\hline
\end{tabular}

Table 1. A summary of marks found on the Terracotta Army

(from 1087 figures found in the easternmost five trenches of Pit 1)

\section{$<<$ Insert Figure 2 here >>}

\subsection{Typology, Semantics and Workshop Practice}

As noted above, the most straightforward classification of marks on the warriors is to distinguish them based on marking method (stamped, incised or painted), and then by content (Figures 2-3). Stamped marks on the terracotta soldiers constitute a fairly clear-cut group, not only for their method of application but also for their content. They normally include the Chinese character Gong (宫 meaning 'palace' or 'royal' and not to be confused with another character I that is also pronounced Gong and rendered the same way in Pinyin, but which has a different meaning, and that we consider separately below) plus one more character that seems to be the personal name of an artisan involved in the figure's manufacture (as argued in greater detail below and on the basis of wider evidence). Occasionally, the Gong (宫) character or an individual's name appears on its own in such stamped marks, but only rarely. Yuan (1990; 2014: 398) has argued, plausibly in our view, that Gong (宫)refers to a central, possibly palace-based workshop (see below for further discussion). These stamped marks must have been impressed in the clay when the latter was still wet and they are invariably placed at the base of the long-skirts of the warriors.

The incised marks can be divided into three groups: (a) those with a similar format to the stamped examples, with a place-name followed by a probable artisan's name, (b) a single Chinese character which seems to be an artisan's name, and (c) those that are 
simple numerals. First and in contrast to the stamped marks, incised examples of placeand person marks very rarely make mention of the Gong (宫) workshop, but instead often mention Xianyang (咸阳 or Xian 咸), the Qin capital city. Likewise, this kind of inscriptional type is normally found in a different location on the warriors to the stamped examples, for example under the arms or on the back of each figure. Beyond these, one terracotta figure, discussed individually below, preserves incised marks mentioning not only Xianyiang (and one personal name) but also three other likely place-names from eastern Qin: Yueyang (栋阳), Linjin (临晋) and Anyi (安邑, two of the latter with personal names). All of them appear written on the same warrior's sleeve, with both this clustering of place-names and the choice of mark location on the warrior's body being unique. These marks also generally seem to have been applied on the clay when it was leather-hard, prior to firing. Some inscriptions also show only the name of the artisan, without any place-name.

Largely distinct from the above two categories of place-and-person marks on the warriors are a series of numerals, typically incised on a warrior's arm or chest. Figure 5a shows that the number 5 (五) occurs most frequently, followed by 4 (四) and 10 (十), with the majority of numerical marks ranging from 2 to 10 . In this front section of the pit, there are also one or two larger incised numbers, as well as evidence for the number 2,000 (二干) on a warrior from more recent trenches excavated further towards the back of pit 1 . As with the incised place-and-person marks above, these incised numerals were mainly applied when the clay was still wet, before firing, although at present it remains impossible to exclude the possibility that a few may have been incised after firing.

A final more elusive category of mark is painted and found only very occasionally on the surface the warriors. More precisely, one Qin character painted in red (Wang, 1994: 568; Yuan and Liu, 2009: 21 and 59) and two numeral characters in black ink have been found in the rear restoration section of Pit 1 (so not part of our core sample of warriors from the front section, but worth mentioning here regardless). Below, we come back to the issue of whether painting such marks on the warriors was only a very rare practice or whether these clues imply a far more widespread practice that is no longer consistently visible on the warriors with the naked eye today. However, for simplicity, we continue to use 'unmarked' to refer to those weapons and warriors that do not have macroscopically visible marks of any kind, albeit without entirely discounting the possibility that these objects once had marks that have now disappeared or preserve vestigial traces that might be observed under non-visible light (the latter approach being a future research agenda).

No matter what methods were used to mark the terracotta warriors, it seems very clear that the above marking evidence relates to the act of manufacture and often refers to the identities and geographic affiliations of their makers. Beyond this simple statement, there remains a host of interesting further insights to explore and the following paragraphs turn to these opportunities. 
The combination of the large number and high perceived individuality of the terracotta warriors has prompted both specialists and the general public to wonder about the status of the producers of these objects: put simply, should we envisage them as artists, artisans or factory workers? For example, Yuan (2014: 398-400) noted the fact that the same format (Gong 宫 plus a personal name) appears frequently on bricks and roof-tiles from both the mausoleum complex and the Qin palace at Xianyang, as well as elsewhere in the vicinity (Xianyang (咸阳), Baoji (宝鸡) and Lintong (临潼)). For example, the Gong (宫) artisan called De not only left an unusually large number of Gong-de or De stamped marks on the warriors from the front of Pit 1, but also left stamped marks on at least two roof-tiles from within the mausoleum complex. Furthermore, a key discovery since the 1990s has been a group of clay seals found in the north suburbs of modern day Xi'an, of which 30 were marked Gongsikong (宫司空, Zhou and Lu 2000: 124-126). This led Yuan to revise earlier suggestions that Gong was an abbreviation of Gongsui (宫水 supposedly the Palace Water Factory) in favour of it referring consistently to Gongsikong (Yuan 2014: 398; see also for previous debate: Yuan and Cheng, 1980; Yuan, 1987; Ledderose, 2000; Barbieri-Low, 2007; Yuan and Liu, 2009: 10-13). Under this new interpretation, Gong (宫) and Gongsikong (宫司空) both refer to a large centralised and quite possibly palace-based, royal workshop that specialised in the production of ceramic construction materials such as bricks and roof tiles (perhaps with Gongsui being a branch factory).

We will elaborate on this argument below with respect to both the warriors and their bronze weapons, but a useful beginning point to make is that these Gong (宫) craftspeople seem less like the mixed-role, ritual/artistic specialists sometimes evoked in discussion of Zhou Dynasty (1100 BC to $22 \mathrm{BC}$ ) or later craft production and much more like attached artisans with the broad potting skills (roof tiles, bricks, drainage pipes) necessary for creating large numbers of large-scale clay figures (in step with comments by Ledderose 2000: 51-73). This being said, the Gong artisans involved do seem to have carried personal seals which makes them stand out from the other markmakers discussed below, and as we shall see, their products appear to be more standardised and/or of better quality than those with other provenance tags. It is therefore tempting to see them as a higher status category of artisan.

The Gong (宫) artisans stamping their seals onto the warriors at the front of Pit 1 include10 people's names: Jiang (疆), De (得), Xi (係), Zang (藏), Kai (刻), Tui (䖽), Zhuang (荘), Po (頗), Wei (巍) and Zhao (朝) which appear on 55 different warriors. The deep impressions of the marks show that these artisans stamped their names on the terracotta figures before firing, and probably as part of some quality checking procedure. However, we will argue in the final discussion below that these named artisans were not only each an overseer of a small group of collaborating but less skillful workers, but were themselves also actively involved in the making process. Regardless, the stamped marks for each artisan have several forms of combination, for example, Gongkai, or Gong Kai separately, or only Kai. Interestingly, Gong and Kai were 
sometimes made by separate seals, and found to be repeatedly used in one location on the warrior, such as Gong, Gong, and Kai. The most productive Gong (宫) artisan in our sample is $D e$ and, to date, 16 terracotta warriors have been found bearing his mark (assuming a male given the personal name). In addition to stamps where Gong (宫) is mentioned explicitly next to a name, two other names are found on stamps on their own: Daqiang (大羥) and Jiang (匠), both on warriors and the bricks from Pit 1 as well as on building materials at other Qin palace sites (Yuan 1990; 2014: 14; Barbieri-Low 2007: 8), and the assumption is that these two artisans were also from the same central governmental workshop responsible for palace and tomb construction.

As noted above and in contrast to the (predominantly stamped) Gong stamps, a second group of artisans leave (incised) marks that repeatedly mention the place-name Xianyiang and it is tempting to identify a second group of artisans, probably chosen from a distinct locus of workshop, somewhere in the capital city, or conscripted from some small private workshops, which also played a major role in production for the mausoleum. Xianyang is mentioned in association with 18 different personal names and is found on 49 different warriors among the 1087 at the front of Pit 1 . In addition, two more were found from Pit 3 and one more each from Pit 2 and the Pit of the Acrobats. These artisans do not seem to have used personal seals to mark their products which is a first suggestion that they may have held lesser status compared to their Gong (宫) colleagues. Finally, a tantalising example is provided by one warrior who preserves mention on his sleeve not only of Xianyang, but also of three other place-names (Yueyang, Linjin and Anyi). Yueyang was one of the old capitals of the pre-imperial Qin state, while Linjin and Anyi were border towns in the pre-imperial era, sometimes under Qin control and sometimes belonging to the Wei and Han states respectively prior to unification. These latter two placenames are also a further clue that the terracotta warriors were produced after or in the latter stages of the Qin state's unification campaign as they are located just inside the borders of what were previously two independent neighboring states. This unusually marked warrior also suggests that there were possibly other contemporary workshops or experienced potters beyond the Qin capital and mausoleum complex area upon which/whom the mausoleum builders might have relied if they chose (but do not seem to have done to any great extent).

Beyond these, there are 36 different individual names found on their own without a place-name ( 3 on the terracotta horses) and therefore at present not attributable to a particular workshop locality (except possibly through future efforts to group warriors based on manufacturing style or raw materials provenance). In addition, there are 183 numerical marks (68 different numbers) on 157 different warriors (with 32 of these numerically-marked figures also bearing stamped and/or incised names): we return in the final discussion to these, but their role remains even more elusive. They could have been made at a slightly different stage of the manufacturing process (see below) and have been used for counting purposes (e.g. as warriors went into the kiln) or they could have functioned as (less informative) indicators of different artisans and their specific groups in much the same way as the textual marks. If the craftspeople involved were not especially literate, they may well have chosen or have been given a number that stayed with them as a signature of their activities. An alternative explanation is that the 
numbers do indeed refer to individual actors but represent some other form of personal classification, such as someone's craft specialty or reason for being on site (e.g. a kind of crime, a kind of military duty, etc.).

\subsection{Mark Positioning and Manufacturing Processes}

A further interesting feature of the warrior marks is the fact that they exhibit regularities in where on the warrior's body they were placed, and in this section we explore such patterns in tandem with a discussion of the manufacturing sequence responsible for producing the terracotta figures.

Each terracotta warrior's body was built from the ground upwards in a succession of body parts made from thick coils of clay, while its head was made and fired separately (with soft clay used to fill gaps between the head and body where necessary). A considerable amount of sculptural detail (robes, other dress elements, scale armour, hair, facial features) was then added separately to the basic human form by hand, before the clay figure was dried in the shade and baked in a kiln. From a logistical point of view, it seems likely that most or all of these manufacturing steps would have occurred in close spatial proximity to one another, as well as close to the clay sources, kilns and pits themselves (see Gao et al. 2002; Lei et al. 2004; Hu et al. 2007 on attempts to source the clay). After firing, the whole terracotta warriors were covered with lacquer before applying various bright pigments (Blansdorf et al. 2001; Bonaduce et al. 2008). They were then placed in their military formation in the pit and equipped with their accompanying weaponry (the sequence of these last steps being plausible rather that unequivocally established).

Although a few unusually shallow, incised marks on certain warriors might conceivably have been made after firing, most marks were made before the warrior was fired in the kiln, implying they were not meant to be seen in the final product and would have been covered up when the warrior was painted. Hence these particular marks are likely to have been associated with bureaucratic oversight (e.g. quality and quantity control) at intermediate rather than final stages of the warrior manufacturing process. The generally poor preservation of the lacquer and paint on the warriors makes it difficult to ascertain whether additional marks were made on them once completed.

Taking each step of the manufacturing process in turn (following the extensive insights made by Yuan $(1990 ; 2014)$, with further commentary where possible), we start with the footboard built for the terracotta warrior to stand on. A few such boards seem to have been made in one piece with the warrior's feet, but at least a few even seem to have been made separately and placed under the warrior after firing (SIAATQ, 1988: 163) The marks observed on the footboard are all incised and include 12 individual personal names, $X u$ (诩 Appendix 1: code 7), An (安 8), Bei (北 9), $Q u$ (屈 11), Shen (申 41), Xiaochi (小遬 21), Yongliu (泳留 23), Gao (高 22), Yi (已 39), Cichi (次速 51), Chen ( 辰 52) and Tian (田 56). The shape of warriors' feet and lower legs exhibit certain typological regularities but seem to have been made by hand, with no clear-cut evidence 
as yet for the use of moulds. After a rough shape was given to the feet, a further thin layer of clay was applied to the surface and sculpted to show muscle and bone structure, as well as puttees and shoes (including laces and exposed soles). The rest of each leg was made either hollow in a series of clay coils, or solid as a clay rod. The marks observed on leg portions are comparatively few (7), but mention the artisans Zhi (穉 Appendix 1: code 25), Shao (少 42), Shan (山 44), Dou (斗 49) and Bing (丙 54). In addition, those Gong marks on the legs mentioning Gong Po (17) and Gong Hui (宫嬇 30) are unusual for being incised (rather than being stamped as was more common practice for Gong marks).

The main body section of a terracotta warrior was built by coiling clay strips upwards in layers that have left visible traces on the interior of broken terracotta figures. As yet, there is no clear evidence to indicate the use of in-the-round moulds, but finger impressions are visible on the interior from where the clay was held in place and shaped (SIAATQ, 1988:170; Yuan, 2014: 436). After the creation of the basic body, more detail sculpturing created the scales and laces of the armour, as well as the creases of the robes. All of the stamped marks mentioning the Gong (宫) workshop, including those also naming artisans Jiang, De, Xi, Zang, Kai, Tui, Chao and Wei, were all placed at the base of the warrior's skirt/robes. In contrast, marks mentioning Xianyang were normally incised on the warriors back or under his arms with a few exceptions found on the chest.

The arms were made separately, mainly via clay coils but in some cases by rolling sheets of clay, and then attaching these to the body. Although incised numerals are found in a variety of locations, it is here on the arms or chest that they are found most often. The hands were shaped differently to match different postures, for example, to match an arm-stretching or half-holding gesture, with detailed fingernails, joints, and muscles. Marks were rarely made on hands and wrists (with the unusual example with multiple place-names noted above therefore being an exception in this way too.

One of the most complicated and important parts of the terracotta figure was the head, and this was probably made first via a basic mould and thereafter via further handsculpting of facial features such as eyes, ears, mouth, nose, beard and hair. At least two different types of mould were used, and each type probably had several stylistic variants. One was a two-piece mould covering front and back halves of the head, with its seam just behind the ears (with broken examples exhibiting their maker's fingerprints and smoothing marks inside each half; SIAATQ 1988: 177; Yuan 2014: 419). Ears were attached after the rough mould, and then the hairline, braids and hair knots were added. Ears were normally shaped by hand and following the further sculpturing. Some braids and topknots were moulded and then stuck on the top of the heads. Two names, Daqiang (code 59) and Jiang (code 47), were found each of them stamped on one head each, and another name Qi (其 code 45) found on a face of the warriors, but name Ran ( 苒 code 12) were incised on the neck of different warriors respectively. A second type is a thin plate containing the facial features with the back two-thirds of the skull formed separately by hand (given it appears rough and uneven inside from finger impressions 
and smoothing). The examples of this second type are seemingly in a minority overall in the pit, but are interesting because they carry marks (most heads do not) with the character Ran incised on the neck. The facial features exhibited by these heads made by the artisan Ran are all similar - with an oval shape, thread-thin eyebrows, large eyes, a long nose, and a wide mouth with thin lips - hence suggesting that at least on occasion we can associate the signature of an artisan with the particular micro-style of a warrior (however, for more tentative evidence that this need not always be so, see Bevan et al. 2014).

Gong (宫)artisans preferred to stamp their names at the bottom of the warrior's robes, while nearly all the Xianyang artisans incised their names on the warrior's back or under his arm. In addition to these dominant locations, 12 different artisan names have also been found on warrior footboards, 7 on the legs of figures, and 4 on the heads (face or neck), but these locations are in a minority. Interestingly, personal names on the different parts of the terracotta warriors rarely overlap with each other: for example, the 4 personal names found on warrior heads, do not appear elsewhere on other terracotta figures. This obviously raises the question of whether artisans were only responsible for certain parts of each warrior, or whether they were responsible for whole figures but only marked their names in specific locations. On balance, it seems that the latter interpretation is more reasonable: a small group of workers may have been responsible for the entirety of each warrior, but beyond this there are suggestions of stylistic similarities amongst those warriors with the same artisan's mark suggesting a particular style was sometimes associated with each leading or master (and presumably marking) artisan. Indeed, the warriors with Gong (宫) marks appear particularly skillful and exhibit unusually robust physiques and features (Yuan 1990; Yuan 2014: 408). For example, the five terracotta figures made by the Gong artisan Tui exhibit similar head and face shapes, even if they carry different facial expressions, while the Xianyang artisan Yue produced soldiers without moustaches that all look younger than others. Likewise, both the stylistic commonalities and manufacturing idiosyncrasies of the (unprovenanced) artisan Ran have already been stressed above.

\subsection{Spatial Analysis}

In addition to considering the spatial patterning of marks on the body of each warrior, we can also look at their spatial distribution across the front part of pit 1. For example, figure 3a shows that there is spatial clustering in the pit with regard to where stamped, incised, numerical and unmarked warriors occur, with these clumps of similarly treated warriors being often less than $10 \mathrm{~m}$ across and thereby comprising anything up to 20 warriors (very roughly). Figure $\mathbf{3 b}$ nuances this picture by indicating that (largely stamped) Gong (宫) marks and (incised) Xianyang marks are likewise clumped spatially, suggesting small-ish groups of warriors were coming from specific workshop locales and being placed in the pit at roughly the same time, in batches. The same figure also shows the location of specific artisans' personal marks (the mapped codes to be read with the help of Appendix 1) and these also exhibit spatial clustering, with a few warriors marked by the same individual found in roughly the same location in the pit. For example, the warriors marked by the Gong artisan named De (code 2, a particularly productive individual to judge from the mark frequencies, as noted earlier) are found in 
groups of between two and five marked warriors together in different sections of one corridor. Likewise, those warriors marked with $X u$ (code 7, marked on footboard) are found in the middle of the front corridor, those with $A n$ (code 8, marked on footboard) in the north-east corner of the pit, and those with Bei (code 9, marked on footboard) and $B u$ (code 10, marked on chest) in similarly-sized clusters elsewhere. These artisans' marks also appear elsewhere in the pit as singletons suggesting that the generative process behind the pattern we observe is nevertheless a noisy one, but that is unsurprising as we would expect artisans (or the small cells/workshops of mixed skill workers they maybe have led, see below) to continue to produce warriors over a longer time period, and perhaps not to mark all of their products in an archaeologically recoverable way (see below).

\section{$<$ Insert Figure 3 here $>>$}

Furthermore, not only do certain single artisan names group spatially, but also several different artisan names co-occur in the same space. For example, the Gong (宫) artisans De, Zang, Xi, Po, Kai, Tui and Chao are found together in two distinct parts of the pit, and it tempting to interpret this inter-mixing as evidence for several individuals (or small subdivision cells they might have been associated with) working concurrently in the same overall workshop.

This impression is reinforced when we return to the question of exactly where on the body of the warriors these artisans were making their marks (Figure 4). As already mentioned the Gong artisans routinely stamped their marks in the same place on the lower, under-part of the warrior's robe. However, the Xianyiang and unprovenanced marks are yet more informative here as, even though they exhibit diversity of mark position overall across the pit, there is a pattern of similar mark positioning by several artisans found in the same section of the pit. Hence, a group of Xianyang artisans (codes $7,13-16,18-20,32-37)$ all mark their warriors on the back or under the arms, whilst in two wholly separate corridors, an overlapping group of artisans unassociated with any placename (Qu, Xiaochi, Yongliu, Shen, and Cichi, codes 11, 21, 23, 41, and 51) are all following the same practice of incising their names on the warriors' footboards. We view these patterns as especially striking because they suggest vestigial 'communities of craft practice', in which multiple artisans collectively decided (perhaps only temporarily) to mark their products for quality and quantity control in similar places on their warriors. Again, this implies batches of warriors made by several different artisans (and their cells) from the same workshop at roughly the same time, arriving to be placed into the pit in small batches. The occasional mix-ups in the otherwise spatially clustered distribution of warrior batches would be consistent with the idea of several workshops operating in parallel, with their respective output meeting near Pit 1 before being placed in their final positions.

\section{$<$ Insert Figure $4>>$}

Turning to a spatial analysis of the numerical inscriptions, it is interesting that, even if we remain unsure of their role, these number marks are likewise clustered in suggestive ways, albeit again with a degree of noise. For example, the number 5 was marked on the shorts of a group of warriors from corridor 10, while the numbers 5 and 6 were all marked on the belly of a group of warriors from corridor 3. Given both (a) the very limited overlap between warriors with textual marks and those with numerical marks 
(albeit not so strong as to be statistically significant), and (b) the propensity of both the textual marks and the numerical marks to exhibit small-scale spatial clustering, one possibility is that these mark types fulfilled similar roles. If this interpretation is correct, then perhaps the numerical marks were merely used by artisans who did not know how to write their name or did not posses a stamp seal. However, an alternative interpretation is that the numerical marks were made at a slightly different stage in the warrior manufacturing process (e.g. perhaps when moving warriors into or out of a kiln).

One further suggestive spatial pattern in the numerical marks is the fact that, in corridor 8 , numbers from 3 to 20 are found together in the same section all marked on the lower right arms. These lower arms in this case were bent in order to hold long weapons and were made separately from the warrior's shoulders and upper arms. Hence, a third possible interpretation, in addition to the possible use of numerical marks (1) as kiln tallies or (2) as identity marks for illiterate artisans, is that (3) they were a mechanism used for keeping track of separate body parts in certain situations. We return to these vying possibilities in the discussion section below.

\section{$<$ Insert Figure 5 >>}

\section{Marks on the bronze weapons}

A particularly interesting, and as yet, under-exploited comparative opportunity arises from the fact that it was not only the terracotta warriors in Pit 1, but also their bronze weapons, that received marks of various kinds (SIAATQ 1988; Yuan 1990; 2014; Li et al. 2011; Li 2012). With this opportunity in mind the following section addresses the marks on different kinds of bronze weapons following a similar structure to the discussion of warrior marks above.

\section{$<$ Insert Figure $6>>$}

\subsection{Typology and Semantics}

As with the warrior marks, there is considerable variety in the detail of the marks made on the bronze weapons or weapon parts (Figure 6), with everything from long, dated texts applied to lances, dagger-axes and halberds, to shorter inscriptions on swords and spears, to simple characters on crossbow triggers and long weapon ferrules to a complete absence of marks on certain weapon categories such as arrowheads or hooks.

In addition to the above typological distinction between more and less complex marks, we can also divide the marks found on Qin bronze weapons into four types, based on whether they were cast, chiselled, incised or painted. Cast inscriptions are mainly found on the stems of the dagger-axes, and only involve the two characters, Sigong (寺工). This term only occurs on bronze weapons and bronze chariot fittings (in contrast to the appearance of the Gong (宫) abbreviation on ceramics) and is assumed to refer yet another centralised and possibly palace-based Qin workshop specialising in metal production (Huang, 1983; 1990; Yuan, 1984; SIAATQ, 1988; Li 2012). Cast marks on 
bronze objects have an older pedigree in China stretching back to the Bronze Age and continuing for a considerable period after the Qin, in contrast to chiselled or incised inscriptions that seem to have been an introduction during the Warring States Period (475 BC to 221 BC) . The presence of two characters Sigong, followed by a person's name, on the bronze weapons probably implies that the person was the official in charge of the centralised metal workshop and had some role in quality control amongst other responsibilities (Huang, 1983; Yuan, 1984). This rendering probably relates closely to, but is not identical with, the mentions in the Shihudi bamboo slips of a Gong Shi (工师 “possibly 'Master of Artisans): “When the quality (of manufactured objects) upon inspection is poor, the Master of Artisans (Gong Shi 工师) is fined one suit of armour (jia 甲), the Assistant (cheng 丞)as well as the Head of the work-squad (caozhang 曹长) (are fined) one shield (dun 盾) and the men (are fined) twenty sets of laces (tuluozu 徒络组)."(Bianxiezu 2001; Hulsewé 1985: C11). The Sigong characters were not only cast on a few bronze weapons but were also carved into lances and ferrules, and the same two characters appear on a Qin chariot fitting and on a bronze vessel discovered in the Qin capital of Xianyang (Yuan1984; Huang 1990). We return to this interesting difference - Gong (宫) on warriors, pottery, bricks, tiles etc. and Sigong ( 寺工) on metal objects - in the discussion at the end.

The distinction between bronze weapons with 'chiselled' marks on the one hand and 'incised' (the latter also referred to below as 'carved') on the other is a more nuanced one. Under close inspection, certain marks exhibit smooth straight lines consistent with a scratching action applied across the surface of the weapon (hence 'incised'), while others exhibit overlapping small triangular impressions from percussive use of a fine chisel ('chiselled') (Li et al. 2011). Both kinds of inscriptions appear on halberds, lances, triggers, swords, and ferrules and some characters were made solely by either carving or chiselling, while others were made using a combination of both carving and chiselling to produce different strokes (Li et al., 2011). Overall, however, whilst this complexity of marking method is worth noting, it is not at present a distinction that appears particularly informative of wider craft practice or logistics.

A final very rare category of marks on the bronze weapons are a series of black painted traces that have been found on at least three crossbow triggers from Pit 1, and appear to have been painted on with a brush. One of these depicted the character Jia (甲) and another $\mathrm{Wu}$ (武). The third example preserves a painted number nine (九) next to a stem-branch character (戊) made by chiselling, and whilst it is clear that these were both made after the trigger was finished by filing, it is not certain in which order the painted and incised marks were made (see Yuan 1984, 1990: 206). In addition to these, one Sigong (寺工) inscription was painted in red on a lance scabbard found elsewhere in Pit 1 (SIAATQ, 1988: 264; Wang, 1994: 569). In the light of these rare examples, final discussion below returns to the difficult question of whether these painted marks were originally far more common, but have not survived well in the archaeological record.

\subsection{Long sentences on lances and halberds}


Long chiselled inscriptions have mainly been found on halberds (and dagger axes) and lances in Pit 1 and their content is especially informative. On the halberds, these mention the term for the major central workshop, Sigong and also a hierarchy of quality control stretching down from occasional mention of an overall supervisor called $\mathrm{Lu}$ Buwei (吕不韦), to a main workshop official, Sigong (寺工), to other craftspeople Cheng

(丞) and the lowest most generic status of worker Gong (工, not to be confused with the Pinyin rendering of 宫, also Gong, referred to on the warriors), all involved in bronze production in some way (SIAATQ, 1988; Yuan 1990; 2014; Li et al., 2011; Li, 2012). In fact, the overall supervisor mentioned here, Lu Buwei, was in fact the chancellor (246237 BC) of the Qin Kingdom before its unification, indicating just how high the recorded chain of official responsibility might reach. Thereafter, the official linked with the Sigong characters was almost certainly the one practically in charge of workshop production, whilst the Cheng artisan may have been a very experienced worker, responsible for obtaining raw materials, training others in the manufacturing process and technology, monitoring the quality of the bronze weapons, and reporting on these practicalities to higher officials. After these officials, the long inscriptions also make reference to the lowest level worker (Gong) and their name, which on present evidence is most likely to have been the real producer of the bronze weapon (SIAATQ 1988; Yuan 1990; 2014; Li et al., 2011; Li, 2012). Finally, another six individual carved characters on the rear of certain halberd stems, alongside the cast Sigong, remains unclear. They might be related to the name of the arsenal in which the halberds were stored (Yuan, 1984; Huang, 1990) or to the person who owned them.

Long inscriptions of this kind also provide the regnal year in which the weapon was produced, thus offering a tantalising clue to the chronology of weapon production. For example, the dates found on seven halberds (of which two are technically better described as dagger axes, i.e. like a halberd but without the spear on the end) all range from 244 to $237 \mathrm{BC}$, before the unification of the Qin Empire in $221 \mathrm{BC}$ (the latter occurring in Qin Shihuang's twenty-sixth regnal year). The chancellor Lu Buwei is mentioned in all of these halberd inscriptions except the latest one (marked for the $10^{\text {th }}$ regnal year, $237 \mathrm{BC}$ ) and this correlates nicely with the date of his fall from power due to supposed involvement with a rebellion. In contrast to the halberds, the long inscriptions found on the spines all 16 lances from the front of Pit 1 show that they were all produced between the fifteenth and nineteenth regnal years (231 to $227 \mathrm{BC}$ ), with these dates missing any mention of a chancellor (as above) but including the Sigong official and a worker's name. The stems of the lances bear one or more further Chinese characters, whose function and meaning remain unclear while the lances' fittings (the part known in Chinese as $\mathrm{Ge}$ ) often also have Sigong inscriptions.

Stepping back, it is tempting to read these differences in detail from halberds produced in 244-237 BC and lances produced from 231-227 BC, as not simply changes in inscriptional brevity, but a rearrangement of workshop bureaucracy in the aftermath of $\mathrm{Lu}$ Buwei's removal, with less formal linkage between the chancellor and weapons production (Yuan 1984; 1990; 2014; Li et al., 2011). If this interpretation is correct, then a second bureaucratic change may thereafter have occurred after the death of the First Emperor, because the chancellor name (now Li Si, Lu Buwei's successor) suddenly 
appears on a weapon (found elsewhere and not from the mausoleum complex) dating to the 1st regnal year of the Qin Second Emperor (209 BC) alongside a new workshop name Yueyang, rather than Sigong (Jiang and Liu 2006).

In any event, regardless of how far this argument about bureaucratic change can be taken, it is striking that the halberds and lances date (a) to a period after Ying Zheng (aka later Qin Shihuang) came to the throne of the Qin Kingdom, but (b) before the unification of the Qin Empire, and (c) from two non-overlapping periods of production despite being found in the same eastern part of Pit 1. One possible explanation is that the weapons were made specifically for the terracotta army and that the mausoleum project began prior unification and as early as $244 \mathrm{BC}$. Under this model, the equipping of the warriors in this part of Pit 1 would have had to have been a very slow process taking place over the course of more than a decade, with the halberds and lances not being produced until they were put into the pit. However, far more plausible, in our view, is the likelihood that groups of halberds, lances and other weapons were often stored in an armoury for some time after they were made (perhaps arriving in the armoury in batches of similar workshop style and date and frequently retaining this similarity to their brethren during storage). On this model, some or all of the equipment for Pit 1 would have been regular Qin military materiél rather than bespoke production for the mausoleum and would have been taken from one or more armouries to the pit rather than being moved directly from the bronze workshops. If this is correct, then it follows (a) that the supply chain for weapons is more complicated than for the clay warriors (whose production was bespoke for the pits alone, even if there are more indirect links to routine production of bricks and pipes) and (b) that the dates on the lances and halberds, whilst interesting for other reasons, are not directly informative about exactly when Pit 1 itself was created (except in giving a terminus post quem of 227 BC). However, some archaeological evidence suggests that Pit 1 was constructed after the unification, including a Qin Imperial bronze coin from the pit (Yuan 2014: 10, and for wider discussion of the chronology, see Zhou et al. 1987; Lu et al. 1988; Nickel, 2007).

\subsection{Marks on crossbow trigger parts}

The inscriptions found on crossbow triggers are much more complicated in terms of their range of signs and the latter's positions on the object. This greater complexity partly derives from the fact that crossbow triggers were complicated mechanical devices composed of five parts assembled together. Not all trigger parts bear an inscription and only $70 \%$ of the 229 triggers from the pit preserve a visible mark on at least one part (SIAATQ 1988; Li et al., 2011; 2014; Li 2012). Altogether 82 different marks have been identified on triggers, including legible Chinese characters, numbers, unknown symbols (whether rare ancient characters undecipherable to us today or more likely just abstract symbols), and some sexagenary (stem-branch) characters. The rationale for this variability in crossbow trigger marks remains slightly elusive, but while it differs in interesting ways from the marks on other weapons or on the warriors, it still shares many of the same priorities with a combination of marks indicating workshop provenance, some potentially expressing calendrical dates and others that 
may well be stand-in symbols for individual workers in the same manner as frequently noted cross-culturally in stone and metal-work (Andrássy et al. 2009).

The crossbow trigger marks were mostly chiselled onto the large, flat surfaces or on the edges of the trigger parts and there is some evidence for multiple marks on different parts, that were meant to match up, with the same character found repeated twice (for instance, on trigger parts $A$ and $B$, or parts $B$ and $C$, or parts $A$ and $C$ ), or three times (parts A, B and C), or even five separate times on the same trigger. Even though the triggers were cast in relatively standardised moulds, with small batches of each part probably cast in stack-moulds (Williams 2008), it was still necessary to file the metal surfaces and mark them during the assembly process to make sure that the trigger parts fitted and could work properly (Li and Gao 2010; Li et al., 2011; 2014). So, while this repetition is not universal, one role for these multiple marks on the triggers may have been to aid reliable assembly by indicating which parts were made in the same mould, by the same worker or at the same time, and would thus best fit together after the filing process (Yuan 1990; Wang 1994). Certainly many of these marks, if not all, were invisible to the end-user of the crossbow, as they were parts of the trigger that was thereafter covered up by the crossbow's wooden stock.

The positioning of the marks on the trigger parts is also interesting as it exhibits a good correlation with the certain stylistic subgroups of triggers that are identifiable by metric and typological observation (see Li 2012; Li et al. 2014). For example, almost all the Gong (工) inscriptions on part B are found on thin side in the inset portion of this part (Figure 7: position $\mathrm{Ba}$ ) suggesting that, as with marking behaviour of the warriors, certain cells of bronze-smiths most likely agreed on a shared practice in this regard (Li 2012). Likewise, those triggers whose marks are placed in position $\mathrm{Ab}$ on part A might belong to the same cell collectively adopting the habit of making marks in same location.

\section{$<$ Insert Figure 7 here $>>$}

\subsection{Other weapon inscriptions}

The bronze swords bear numbers and stem-branch characters chiselled mainly on their stems, and include the characters four, six, seventy-seven, eighty-eight, fifty-eight, one, two, five, and a single stem-branch character Ren (壬) (SIAATQ 1988; Li 2012).

Ferrules are small bronze caps that were fitted to the butt end of long weapons and some also bear inscriptions, in all cases referring to Sigong. In fact, only one kind of ferrule (Li 2012: type III; Fig8) bears inscriptions and there is good reason to suggest that this type was always associated with lances. Exactly half of the ferrules of this type were inscribed (25 out of 50 in the five easternmost trenches of pit1) presumably due to prevailing workshop practices, such as manufacture in pairs or quality control of every second example. 


\subsection{Spatial Analysis}

In addition to, or in combination with, this variable positioning of marks on different parts of a weapon, we can also look at the spatial distribution of different weapon marks across the front part of pit 1 . For example, those trigger part Bs identified in a previous study (Li 2012; Li et al 2014) as being fractionally different in shape and style are marked Gong or with other characters in the Ba position on the narrow side of a notch (Figure 7), and these cluster spatially in certain parts of certain corridors in Pit 1. Such patterns remain noisy and do not match the spatial patterns exhibited by the warrior marks, but regardless they do again suggest communities of craft practice, in this case of bronze-workers, surviving from workshop to arsenal to pit.

Turning to the long weapons, our sample of halberds, dagger axes and lances is rather small and the location of regnal years or particular artisans' names does not exhibit any clear spatial pattern. The small sample is particularly suspicious, with only 5 halberds and 17 lances in Pit 1 compared to 126 surviving ferrules that were the butt-ends of such weapons (Li 2012). Unless there were a large number of quarterstaffs or flags (which seems unlikely entirely to explain the discrepancy), then we must assume that a reasonably large number of the edge-ends of these long weapons have been lost, perhaps due to the roof collapse and subsequent looting of material from the topmost layers of the pit (which might have removed the top of weapons but not their bottoms). The spatial patterning of these lance ferrules suggests that the marked examples are fairly evenly distributed (with about half marked in each corridor).

\section{Discussion}

There are a host of interesting topics of discussion that might be prompted by the above patterns in marking practice, but we will focus on their implications for our understanding of workshop practice and the wider context of mark-making in Qin society.

It is worth first reiterating a major probable difference in production logistics between the warriors and their weapons. As argued above, the bronze weapons with long inscriptions from Pit 1 were most likely manufactured as part of the regular military supply chain with sharping blade (Li et al. 2011; Li 2012); out of a probable wider set of workshops at different regional centres across the Qin state that might have provided such items, it seems that many of the Pit 1 weapons were made by an important central workshop (Sigong 寺工) in or near the Qin capital (about $50 \mathrm{~km}$ away from the mausoleum). Although a proper investigation of whether these weapons exhibit clear signs of prior use has not yet been conducted, their date suggests they were probably stored in an armoury (or several such establishments, in some cases for over a decade) and this raises the possibility that they may also have seen prior use, before to their final movement to the pit. In contrast, perhaps the bronze crossbow triggers (which exhibit lots of filing marks, but few if any obvious wear marks, Li et al. 2011; 2014) and more confidently the bronze arrows (most of them in bundles with shape and 
geochemical consistencies that do not suggest post-production mixing, Li 2012; Martinón-Torres et al. 2014) were more likely to have been bespoke products to equip the Terracotta Army, albeit still functional, lethal weapons. In contrast, although the warriors certainly borrowed techniques and labour strategies linked to routine manufacturing processes such as tile, pipe or brick-making, they were a bespoke initiative for the mausoleum itself and produced locally. It is unsurprising therefore, but worth emphasising, that the spatial patterns in warrior marks in Pit 1 on the one hand, and those of the weapon marks and microstyles on the other, do not seem strongly correlated (i.e. whilst there are important spatial clusters of marks for both weapons and warriors, these clusters are not identical). Hence, we would conclude that the warriors and weapons marks exhibit patterns that inform us far more about their prior manufacturing history before arriving in the pit, but that these patterns are not the same. In this sense, although the workforce appears to have been organised logistically in versatile cells of artisans, it is likely that different workshops were responsible for of warrior-making and weapon-making respectively, and that their finished products only met at the point where they were brought down into the pit.

Despite these differences, it is still tempting to see mark-making on both warriors and weapons as a quality control practice that co-evolved in Qin society with the development of factory-like, assembly-line approaches to manufacture (Barbieri-Low 2007: 4-10, 74-79). Certainly, the Shuihudi slips suggest the marks might enable a hierarchical system of fining the chain of workers and officials involved in the weapons manufacture if it was sub-standard. The verbose, hierarchically organised long inscriptions on halberds and lances (but potentially the simpler ones too) (also see Li et al. 2011; Li 2012) corroborate this view of a chain of responsibility that is a salient feature of Qin law across other domains as well (such as village life or the army; see Loewe 2007; 2010). However, we have argued before on the basis of metrical, chemical and spatial analysis of the bronze weapons (Li et al. 2014; Martinón-Torres et al. 2014) that manufacture was probably organised via small groups of workers organised in to cells. While it is possible that (a) multiple cells of this kind sometimes worked alongside each other in the same overall workshop at the same time), and (b) individual workers in a cell sometimes focused on certain sub-tasks, the current evidence suggests to us that each workshop unit was responsible for turning out complete functioning weapons. The 'assembly-line' analogy is, in our view, therefore a misleading one, and so too is the idea that it was the need to keep track of complicated proto-Fordist production chains that drove forward the use of product marks. Similarly, the groups of warriors that appear in clusters with the same makers' marks and artisanal 'styles' would seem to argue against the claim that the highly diverse, life-like appearance of the army overall is the result of countless combinations of a limited set of 'modules' of body parts (see Ledderose 2000: 51-73).

Nor was quality control (whilst clearly important) the only reason for marks. For example, the same inscriptions on the fitted trigger parts could also act as guides to assembly of those product parts that might best fit together (because, amongst an array of fairly standardised parts, those with the same mark were likely to be still more consistent in shape). Another example are the numerical marks 3 to 20 only found on the lower arms of warriors in corridor 6 that would seem to be related to the counting 
of products. We are tempted to read at least one section of the Shuihudi records as referring to these assembly concerns: “When quarterstaffs [shu 殳], halberds [ $j i$ 戟], and crossbows [nu 㛎] (marked) in black or red (literally lacquer and cinnabar, xiutong 髹䑣) have become confused (xiangyi 相易), this is not to be considered as a surplus or a shortage but is to be condemned according to Statute concerning marks not corresponding to the register." (Hulsewé 1985: B21). Likewise, a final set of marks was meant to be visible to the end-user on finished objects and could be used as a form of accounting as weapons came into and out of the armoury. In particular, the Shuihudi slips prescribe that Qin weapons were to be incised ( $k e$ 刻) or branded (jiu 久, aka stamped) with the name of the office concerned as follows: "Government armour and arms are each to be incised [ke 刻] or branded [jiu 久] with the name of the office concerned; on those that cannot be incised or branded, it should be written with vermillion [dan 丹, aka the colour red] or lacquer [qi 漆, aka the colour black]. When armour and arms are loaned to commoners, it is essential to record the brand-mark [jiu 久]; they are to be bestowed according to the brand-marks. When loaned (armour and arms) are handed in and they have no brand-mark, as well as when it is not the brandmark of the office concerned, (such armour and arms) are all to be confiscated by the government; they are to be charged according to the Statutes on Equipment." (Bianxiezu 2001; Hulsewé 1985: A56). When weapons were loaned out, a note was to be made of the mark as a way of keeping track of the loaned inventory, with penalties in place if, on its return, the mark on the weapon did not match the recorded one. It is unclear as yet whether some chiseled marks on the weapons were those used administratively to manage such loans or whether the few painted black or vermillion marks found on the weapons are a clue towards wider use of temporary/renewable painted marks as records of the kinds of weapon loans described in the Shuihudi Bamboo slips.

The suggestion that some marks were meant to be visible raises some interesting questions. From the Pit 1 weapon assemblage, for example, we can point to the inscriptions on the blades of lances and halberds or the Sigong marks on the ferrules as most likely remaining visible to an observer on the finished long weapon. In contrast, the marks on the trigger parts would clearly no longer be visible when placed into a wooden crossbow stock and it is tempting to explain their more eclectic character (numerals, names, stem-branch characters, etc.) as reflecting a less long-term marking practice mainly relevant in the workshop or in the unlikely event that the trigger parts became disarticulated during use. It is also quite possible that the wooden section of the finished crossbow was marked, but these parts no longer survive. This last suggestion brings us to the question of how partial is our sample of surviving marks in Pit 1 . It is very likely that some lacquer or vermillion marks have not always survived well on ceramic, metal or wooden surfaces. Further inspection of these weapons under UV light or via multi-spectral imaging offers one potential way to address this issue in future.

A final point to note with regard to the weapons and the further insights provided by contemporary written sources comes from a vast group of Qin bamboo slips found at Liye in south-west China. The latter town was a medium-sized centre (below commandery level) located in the recently conquered former state of Chu. While Shuihudi slips provide us with prescriptive legal texts promulgated from the centre, the 
Liye archive nicely demonstrates how local bureaucrats in a provincial town attempted to implement the same laws. Amongst a range of interesting evidence from this source, one important mention is of the routine production of crossbows and bolts for a local armoury, using local resources such as lacquer and chicken or wild pheasant feathers for arrow fletching (Hunan Provincial Institute of Archaeology 2012; Yates 2013: 303304). In particular, the crossbows were delivered to other cities from Liye: "Sum in Qianling: 169 crossbows were stored arsenal in 34th regnal year (213BC). Altogether 169 crossbows. Four crossbows were distributed to Yiyang. Three crossbows were distributed to Linyuan. Altogether seven crossbows were given out. In August this year, 162 crossbows remain." (Hunan Provincial Institute of Archaeology 2006: 183, board 8.147). This suggests we should expect local workshops and weapons stores throughout the Qin state, of which the mausoleum project perhaps drew primarily upon the most central. The place-names preserved by the warrior marks also suggest a central provision of craftspeople (conceivably moved to the mausoleum site to make the warriors), but also occasional mention of other places. Lurking in the evidence of crossbow marks and microstyle is further evidence of a similar pattern of a major central metal workshop but also devolved alternatives, conceivably in other places ( $\mathrm{Li}$ et al. 2014). Further high-resolution geochemical analyses of the raw materials employed for metals, warriors and other elements of the mausoleum may help clarify if the workshops supplying the site worked in proximity of each other and/or if they shared raw material sources.

Artisans constituted a major professional class in Qin and later imperial China whose identity, status, literacy and mobility are all of considerable interest. They not only might come from more central or more provincial locations, but clearly brought differing levels of personal skill and seemingly held varying status in Qin society. Certain artisans were clearly of 'commoner' status (shih-wu, 士五) given that lacquered eared cups found in the same Shuihudi tomb 11 that produced the slips mentioned their maker's status (Bianxiezu 1981; 2001; Hulsewé 1985). However, the bamboo slips also make it clear that, under certain circumstances, slaves, convicts and soldiers could all become low-level Gong (工) workers and thereby escape other obligations (SQZZX 1988; Bianxiezu 1981; 2001; Yuan 1984; 1990: 200). Such peripheral groups were, ironically, quite familiar with body marking practices associated with their low status, as these were the main groups in the core Chinese area who were tattooed (bodymarking otherwise being a practice more strongly associated with barbarians, see Reed 2000). Indeed, the Shuihudi slips mention tattooing (quíng 黝) as a relatively light form of legal punishment, perhaps more severe than a fine, hard labour or hair-shaving, but less severe than bodily amputations (e.g. Hulsewé 1985: 15, D25, D27-28, D62, D154). It is worth stressing that the marks on the warriors rarely, if ever, imitate such practices directly, usually being placed on top of the depicted clothing rather than on the skin. However, the more general concept of categorising and marshalling individuals via the application of words and numbers to the human body nonetheless cross-cuts clay and flesh in interesting ways.

In any case, at the top of the craft pyramid are clearly the central Gong (宫) artisans who sometimes owned personal stamps and were the ones responsible for the most 
consistent quality warriors. The marks also suggest a possible spectrum of artisan literacy from this top group who seem to have been able to read and write verbose long inscriptions. Conceivably however, there was also a less literate group and one interpretation offered above for the numerical marks found on the warriors being that they were a practice adopted by a group of artisans who could not write. Stepping back, the very appearance of a vast apparatus of literate and semi-literate marking at this time can be juxtaposed with a slow expansion of literacy to wider group of jurists, military specialists, bureaucrats and artisans over the course of the later $1^{\text {st }}$ millennium BC (as also indicated by the increased visibility of various kinds of written professional manual, Yates 1988: 242-243).

Finally, it is worth ending with some speculation about possible groupings of artisans and their products in the context of wider discussion of Qin 'legalist' doctrine. It is striking the extent to which the Qin state extended its bureaucratic reach into all sectors of society, forcing the registration of the entire population and its organisation into mutual responsibility groups that were punished or rewarded based on their services to the state (Loewe 2007; Pines 2014; Pines et al. 2014). The earlier Qin reorganisation of society into five- ten- family units remained an important structuring principle down into the imperial phase, and the role of these groups in military recruitment meant that a five-person team remained the minimal unit of military organisation as well (Yates 1987; Loewe 2010). It is difficult to know if artisans were likewise registered in five person units (e.g separately from the ordinary five-family groups), but the evidence from Pit 1 does circumstantially suggest a range of ways in which the workers may have operated on the model of small groups of about this size. For example, our model of small workshops suggests habitually collaborating groups of about this scale. Likewise, the numerical marks found on the warriors are usually 10 or less with an overrepresentation of the numbers 5 and 10 (Figure 5a). Both the spatial distribution of crossbow trigger microstyles (Li et al 2014: fig.9 dotted circle) and the spatial grouping of mark locations and artisan names on the warriors also argue for small-scale groupings of about this order (Figure 4) responsible for laying out and equipping of small groups of warriors in one go. Although the argument cannot be pushed very far at present, it is at least worth thinking that both the artisans and the army they were making in Pit 1 were organised according to some very familiar principles. In this sense, just as the mausoleum is often taken as a material representation of the Emperor's broader universe (Rawson 2007), its very construction may also be viewed as microcosm of the same organisational policies that supported the emergence of the empire.

\section{References}

Andrássy, P., Budka, J. and Kammerzell, F. (eds.) 2009. Non-Textual Marking Systems, Writing and Pseudo Script from Prehistory to Modern Times: 215-231. Göttingen: Seminar fur Ägyptologie und Koptologie.

Bachmann, M. 2009. Hellenistishce steinmetzmarken im westlichen Kleinasien, in Andrássy, P., Budka, J. and Kammerzell, F. (eds.) Non-Textual Marking Systems, Writing 
and Pseudo Script from Prehistory to Modern Times: 215-231. Göttingen: Seminar fur Ägyptologie und Koptologie.

Barbieri-Low, A.L. 2007. Artisans in Early Imperial China. Seattle: University of Washington Press.

Bevan, A., Crema, E., Li, X. and Palmisano, A. 2013. Intensities, interactions and uncertainties: some new approaches to archaeological distributions, in Bevan, A. and Lake, M. (eds.) Computational Approaches to Archeological Spaces, Walnut Creek: Left Coast Press.

Bevan, A.H., Li, X.J., Martinón-Torres, M., Green, S., Xia, Y., Zhao, K., Cao, W., and Th. Rehren 2014. Computer vision, archaeological classification and China's Terracotta Warriors. Journal of Archaeological Science, 49 (1), 249-254. doi:10.1016/j.jas.2014.05.014

Bianxiezu (editing group) of Yunmeng Shuihudi Qin tomb. 1981. Yunmeng Shuihudi Qin mu (Yunmeng Shuihudi Qin tomb). Beijing: Wenwu Press.

Bianxiezu (editing group) of Shuihudi Qin Bamboo Slips. 2001. Shuihudi Qin mu zhujian (Bamboo slips discovered in the Qin tomb at Shuihudi). Beijing: Wenwu Press.

Blänsdorf, C., Emmerling., E., and Petzet, M. (ed.). 2001. The Terracotta Army of the First Chinese Emperor Qin Shihuang. München: Monuments and Sites.

Blonde , F. and Muller , A . (eds .) 1998. L'Artisanat en Grèce Ancienne: Les Artisans. Les Ateliers, Topoi 8.2 (Special Issue): 543-845.

Bonaduce, I., Blänsdorf, C., Dictemann, P., et al. 2008. The binding media of the polychromy of Qin Shihuang's terracotta army. J Cult Herit, 9: 103-108.

Chaniotis, A. 2005. War in the Hellenistic world: a social and cultural history. Oxford: Blackwell Publishing.

de Maaijer, R. 2001. Late Third Millennium identifying marks. In W. H. van Soldt (Ed.), Studies Presented to Klaas R. Veenhof on the Occasion of His Sixty-Fifth Birthday: 300-324. Leiden: Netherlands Institute for the Near East. 
Eerkens J. W. and R. L. Bettinger 2001. Techniques for assessing

standardisation in artefact assemblages: can we scale material variability?

American Antiquity 66, 493-504.

Eerkens, J. W. and C. P. Lipo 2005. Cultural transmission, copy errors, and the generation of variation in material culture and the archaeological record.

Journal of Anthropological Archaeology 24, 316-334.

Foxvog, D.A. 1995. Sumerian brands and branding irons. Zeitschrift für Assyriologie und Vordasiatische Archäologie 85:1-7.

Gao, Z.Y., Zhao, W.J., Li, G.X., Xie, J.Z., Han, G.H., Feng, S.L., Fan, D.Y., Zhang, Y., Chai, Z.F., Li, R.W., Zhang, Z.L., Zhu, J.X., 2002. Neutron activation analysis on the raw material of terracotta warriors and horses of Qin Shihuang Mausoleum. Science in China (G) 32: 900-906.

Harris , W.V . (ed.) 1993. The Inscribed Economy: Production and Distribution in the Roman Empire in the Light of Instrumentum Domesticum. Ann Arbor: University of Michigan.

Hu, Y-Q., Zhang, Z-L., Bera, S., Ferguson, D.K., Li, C-S., Shao, W-B., Wang, Y-F. 2007. What can pollen grains from the Terracotta Army tell us? Journal of Archaeological Science 34(7): 1153-1157.

Huang Shengzhang 1980 Yunmeng Qin mu liangfeng jiaxin zhong youguan lishi dili de wenti (Two letters on bamboo slips from the Qin tomb found in Yunmeng). Wenwu, 1980: 08, p74-77.

Huang Shengzhang 1983. Sigong xin kao (A reinterpretation on Sigong inscription). Kaoku, 1983: 09, 829-833.

Huang Shengzhang 1990. Qinyong keng chutu bingqi mingwen yu xiangguan zhidu fafu (Inscriptions on the bronze weapons for the Qin Terracotta Warriors and related systems). Wenbo, 1990: 05, 63-71. 
Hunan Provincial Institute of Archaeology 2006. Liye Fajue Baogao (Report on the Excavation of Liye Site). Changsha: Yuelu Publishing House.

Hunan Provincial Institute of Archaeology 2012.Liye qinjian - yi (Liye Qin slips and boards - Volume One). Beijing: Wenwu Press.

Hulsewé, A.F.P. 1985. Remnants of Ch'in Law: An Annotated Translation of the Ch'in Legal and Administrative Rules of the 3rd Century BC. (Sinica Leidensia, No 17) Leiden: Brill.

Jiang, Wenxiao and Liu Zhancheng 2006. Qinyongkeng xin chutu ge ji yanjiu (Research on the newly discovered bronze dagger-axe and halberd from the pit of the Terracotta Army). Wenwu, 2006: 03, 66-71.

Kern, M. 2000 The Stele Inscriptions of Ch'in Shih-huang: Text and Ritual in Early Chinese Imperial Representation. New Haven: American Oriental Society.

Ledderose, L. 2000.Ten thousand things. Module and mass production in chinese art. Princeton, NJ:Princeton University Press.

Lei, Y., Guo, B., Yuan, S. 2004 Neutron activation analysis for the provenance study on Terracotta Army of Qin Shihuang. Nuclear Techniques, vol.27: 38-27.

Li Xiuzhen and Gao Jun 2010 Cong qingtong nuji mingwen kan Qin qingtong bingqi shengchan biaozhunhua de jvxianxing (The limitation of standardisation of production for the Qin bronze weapon - a case study on the inscriptions carved on the crossbow triggers). Wenbo, 2010, vol. 2: 43-46.

Li, X., Martinón-Torres, M., Meeks, N. D., Xia, Y. and K. Zhao. 2011. Inscriptions, filing, grinding and polishing marks on the bronze weapons from the Qin Terracotta Army in China. Journal of Archaeological Science 38, 492-501.

Li, X. 2012. Standardisation, Labour Organisation and the Bronze Weapons of the Qin Terracotta warriors. PhD Thesis. London: University College London.

Li, X., Martinón-Torres, M., Meeks, N. D., and Y., Xia. 2012. Scanning electron microscopy imaging of tool marks on Qin bronze weaopns using silicone rubber impressions, in N. Meeks, C. Cartwright, A. Meek and A. Mongiatti (eds.), Historical Technology, Materials and Conservation: SEM and Microanalysis, 62-68. London: Archetype and The British Museum.

Li, X., Bevan, A,, Martinón-Torres, M., Rehren, Th., Cao W., Xia, Y. and K. Zhao 2014. Crossbows and imperial craft organisation: the bronze triggers of China's Terracotta Army. Antiquity 88, 126-140.

Loewe, M. 2007. The First Emperor and the Qin Empire. In J. Portal (ed.), The First Emperor - China's Terra-cotta Army (pp58-79). London: The British Museum Press. 
Loewe, M. 2010. Social distinctions, groups and privileges, in M. Nylan and M. Loewe (eds.), China's Early Empires: A Re-appraisal. Cambridge: Cambridge University Press, 296-307.

Lu Yanshi, Zhang Jingzhao, Xie Jun, and Wang Xueli 1988. TL dating of pottery sherds and baked soil from the Xian Terracotta Army Site, Shaanxi Province, China. International Journal of Radiation Applications and Instrumentation. Part D. Nuclear Tracks and Radiation Measurements 14(1-2): 283-286.

Martinón-Torres, M., Li, X., Bevan, A., Xia, Y., Zhao, K., and Th. Rehren. 2011. Making weapons for the Terracotta Army. Archaeological International, 13/14 (2009-2011), 6575.

Martinón-Torres, M., Li, X., Bevan, A., Xia, Y., Zhao, K., and Th. Rehren. 2014. Forty thousand arms for a single emperor: from chemical data to labor organization in the production of bronze arrows for the Terracotta Army. Journal of Archaeological Method and Theory, September, vol 21, 534-562. DOI: 10.1007/s10816-012-9158-z

Nickel, L., 2007. The Terracotta Army. In J. Portal (ed.), The First Emperor - China's Terracotta Army (pp. 114-151). London: The British Museum Press.

Pines Y., von Falkenhausen L., Shelach G., and Yates, R.D.S. (eds.) 2014. Birth of an Empire - the State of Qin Revisited. Los Angeles: University of California Press.

Pines, Y, 2014. "Legalism in Chinese Philosophy", The Stanford Encyclopedia of Philosophy (Winter 2014 Edition), Edward N. Zalta (ed.), URL = http://plato.stanford.edu/archives/win2014/entries/chinese-legalism/ [accessed 14/06/2015]

Rawson, J. 2007. The first emperor's tomb: the afterlife universe. In J. Portal (ed.), The First Emperor - China's Terracotta Army (pp. 114-151). London: The British Museum Press.

Reed, C.E. 2000. Early Chinese tattoo. Sino-Platonic Papers 103: 1:52.

SIAATQ (Shaanxi Institute of Archaeology and Archaeological Team of Qinshihuangling). 1988. Qinshihuang Ling Bingmayong Keng - Yihao Keng Fajue Baogao 1974-1984 [An 
excavation report on Pit 1 of the terracotta warriors and horses for the Emperor Qin Shihuang 1974-1984]. Beijing: Cultural Relics Press.

Wagensonner, K. 2009. Non-textuality in the Near East. Some glimpses from the Mesopotamian field, in Andrássy, P., Budka, J. and Kammerzell, F. (eds.) Non-Textual Marking Systems, Writing and Pseudo Script from Prehistory to Modern Times: 33-67. Göttingen: Seminar fur Ägyptologie und Koptologie.

Wang Xueli 1994. Qin yong zhuanti yanjiu (A monograph of the Qin Terracotta Warriors). Xi'an: Sanqin Press.

Wengrow, D. 2008. Prehistories of commodity branding, Current Anthropology 49:7-34.

Williams, D. 2008. Mass-produced pre-Han Chinese bronze crossbow triggers: unparalleled manufacturing technology in the Ancient World. Arms and Armour 5(2): 142-153.

Yates, R.D.S. 1987. Social status in the Ch'in: evidence from the Yün-meng legal documents. Part One: Commoners, Harvard Journal of Asiatic Studies 47.1:

211-248.

Yates, R.D.S. 1988. New light on ancient Chinese military texts: Notes on their nature and evolution, and the development of military specialization in Warring States China, T'oung Pao 74.4-5: 211-248.

Yates, R.D.S 2013. The Qin slips and boards from Well No. 1, Liye, Hunan: A brief introduction to the Qin Qianling county archives, Early China 35: 291-329.

Yuan Zhongyi 1984. Qin zhongyang du zhao keci zhongshu (A comprehensive research on the Qin weapons' inscription and governmental control on their production). Kaoguoyuwenwu, 1984: 05, 101-112.

Yuan Zhongyi and Cheng Xuehua 1980. Qin dai zhongyang guanshu zhitaoye de taowen (Pottery inscriptions about the governmental pottery workshops of the Qin Dynasty). Kaoguyuwenwu, 1980: 03, 11-19.

Yuan Zhongyi 1987. Qin dai taowen (Qin pottery inscriptions). Xian: Sanqin Press. 
Yuan Zhongyi 1990. Qin Shihuangling bingmayong yanjiu (A research on the terracotta warriors and horses from the Qin First Emperor's mausoleum complex). Beijing: Wenwu Press.

Yuang Zhongyi 2002. Qin Shihuangling kaogu faxian yu yanjiu (Archaeological discoveries and research on the Emperor Qin Shihuang's tomb complex). Xi'an: Shanxi Renmin Press.

Yuang Zhongyi and Liu Yu 2009. Qin taowen xinbian (New collection and interpretation on the Qin pottery inscriptions). Beijing: Wenwu Press

Yuan Zhongyi 2014. Qin bingmayong de kaogu faxian yu yanjiu (Archaeological discoveries and research on the Qin terracotta warriors). Beijing: Wenwu Press.

Zhou Mingfu, Zhou Weijian, Yang Liping and Wang Xueli 1987. Bingmayong (14)G nianling (Dating about the terracotta warriors (14) G). Bulletin of Mineralogy, Petrology and Geochemistry, 1987: 04, 229-230.

Zhou Xiaolu and Lu Dongzhi 2000. Qin fengni ji (Collection of the Qin seals). Xi'an: Sanqin Press.

\section{Appendix 1. Codes for the textual marks found on the warriors}

A ';' is used to distinguish two or more, separate marks on a warrior. 


\begin{tabular}{|c|c|c|c|c|}
\hline Code & Chinese & Pinyin & Method & Location \\
\hline 1 & 宫彊 & Gong Jiang & Stamped & Robe \\
\hline 2 & 宫得 得 & Gong De; De & Stamped & Robe \\
\hline 3 & 宫系系 & Gong Xi; Xi & Stamped & Robe \\
\hline 4 & 宫臓 藏 & Gong Zang; Zang & Stamped & Robe \\
\hline 5 & 宫欬 & Gong Kai & Stamped & Robe \\
\hline 6 & 宫樻 & Gong Tui & Stamped & Robe \\
\hline 7 & 咸诩 诩 & Xian Xu; Xu & Incised & Belly, Footboard \\
\hline 8 & 安 & An & Incised & Footboard \\
\hline 9 & 北 & Bei & Incised & Footboard \\
\hline 10 & 不 & $\mathrm{Bu}$ & Incised & \\
\hline 11 & 屈 & $\mathrm{Qu}$ & Incised & Footboard \\
\hline 12 & 再 & Ran & Incised & Neck \\
\hline 13 & 咸行行 & Xian Xing; Xing & Incised & Back \\
\hline 14 & 咸阳秸 咸秸 秸 & $\begin{array}{l}\text { Xianyang Jie; Xian } \\
\text { Jie; Jie }\end{array}$ & Incised & Back \\
\hline 15 & 咸妳妳 & Xian Er; Er & Incised & Back \\
\hline 16 & 咸敬 & Xian Jing & Incised & Back \\
\hline 17 & 宫颇 颇 & Gong Po; Po & Stamped, Incised & Robe, Leg \\
\hline 18 & 咸阳危 & Xianyang Wei & Incised & Back \\
\hline 19 & 咸阳路工路 & $\begin{array}{l}\text { Xianyang Lu; Gong } \\
\mathrm{Lu}\end{array}$ & Incised & Back \\
\hline 20 & 咸阳午 咸午 午 & $\begin{array}{l}\text { Xianyang } \mathrm{Wu} \text {; Xian } \\
\mathrm{Wu} ; \mathrm{Wu}\end{array}$ & Incised & Back \\
\hline 21 & 小遫 & Xiaochi & Incised & Footboard \\
\hline 22 & 咸阳高 高 & Xianyang Gao; Gao & Incised & Wrist, Footboard \\
\hline 23 & 詠留 & Yongliu & Incised & Footboard \\
\hline 24 & 越 & Yue & Incised & \\
\hline 25 & 咸穉 称 & Xian Zhi; Zhi & Incised & Back, Leg \\
\hline 26 & 咸阳野 咸野 & $\begin{array}{l}\text { Xianyang Ye; Xian } \\
\text { Ye }\end{array}$ & Incised & Bacl \\
\hline 27 & 咸阳 & Xianyang & Incised & Back \\
\hline 28 & 宫荘 & Gong Zhuang & Stamped & Robe \\
\hline 29 & 宫朝 & Gong Chao & Stamped & Robe \\
\hline 30 & 宫嬇 & Gong Hui & Incised & Leg \\
\hline 31 & 宫魏 & Gong Wei & Stamped & Robe \\
\hline 32 & 咸处 & Gong Chu & Incised & Back \\
\hline 33 & 咸庆 & Xian Qing & Incised & Back \\
\hline 34 & 咸阳賜 & Xianyang Chi & Incised & Back \\
\hline 35 & 咸阳笴 & Xianyang Ke & Incised & Back \\
\hline
\end{tabular}




\begin{tabular}{|l|l|l|l|l|}
\hline 36 & 咸阳木 & Xianyang Mu & Incised & Back \\
\hline 37 & 咸阳衣咸衣 & $\begin{array}{l}\text { Xianyang Yi; Xian } \\
\text { Yi }\end{array}$ & Incised & Back \\
\hline 38 & 杏 & Xing (on horse) & Incised & Horse \\
\hline 39 & 已 & Yi & Incised & Footboard \\
\hline 40 & 由 & You & Incised & \\
\hline 41 & 申 & Shen & Incised & Footboard \\
\hline 42 & 少 & Shao & Incised & Leg \\
\hline 43 & 尚 & Shang & Incised & \\
\hline 44 & 山 & Shan & Incised & Leg \\
\hline 45 & 其 & Qi & Incised & Neck \\
\hline 46 & 民 & Min & Incised & \\
\hline 47 & 匠 & Iiang & Stamped & Head \\
\hline 48 & 捍 & Han & Incised & \\
\hline 49 & 斗 & Dou & Incised & Leg \\
\hline 50 & 畣 & Da (on horse) & Incised & Horse \\
\hline 51 & 次速 & Ci Chi & Incised & Footboard \\
\hline 52 & 辰 & Chen & Incised & Footboard \\
\hline 53 & 鉼 & Bing & Incised & \\
\hline 54 & 丙 & Bing & Incised & Leg \\
\hline 55 & 王 & Wang & Incised & \\
\hline 56 & 田 & Tian & Incised & Footboard \\
\hline 57 & 丰八 & Fengba & Incised & \\
\hline 58 & 中 & Zhong & Incised & \\
\hline 59 & 大羥 & Da Qiang & Stamped & Head \\
\hline 60 & 脾 & Pi & Incised & \\
\hline 61 & 棉阳重 & Yueyang Zhong & Incised & Wrist \\
\hline 62 & 临晋乘 & Linjin Cheng & Incised & Wrist \\
\hline 63 & 安邑 & Anyi & Incised & Wrist \\
\hline 64 & 悁 & Suan & Incised & \\
\hline 65 & 野 & Wen (on horse) & Incised & Horse \\
\hline 66 & 文 & & \\
\hline & & & \\
\hline
\end{tabular}




\section{Figure Captions}
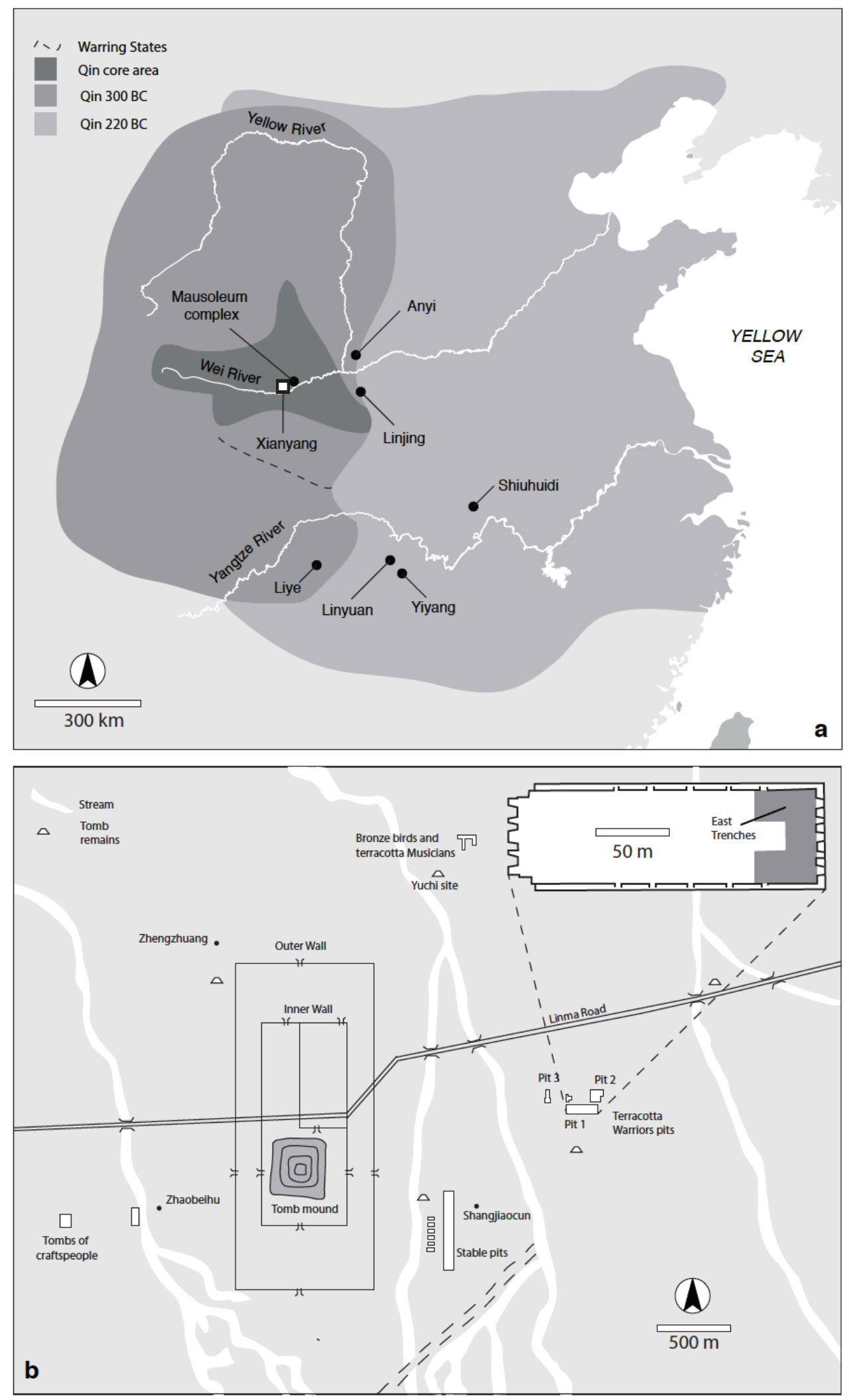

1. (a) The heartland of the Qin state and a rough impression of the territorial extent of the Qin empire, with sites mentioned in the text, and (b) a plan of the mausoleum complex, with Pit 1 shown inset. 

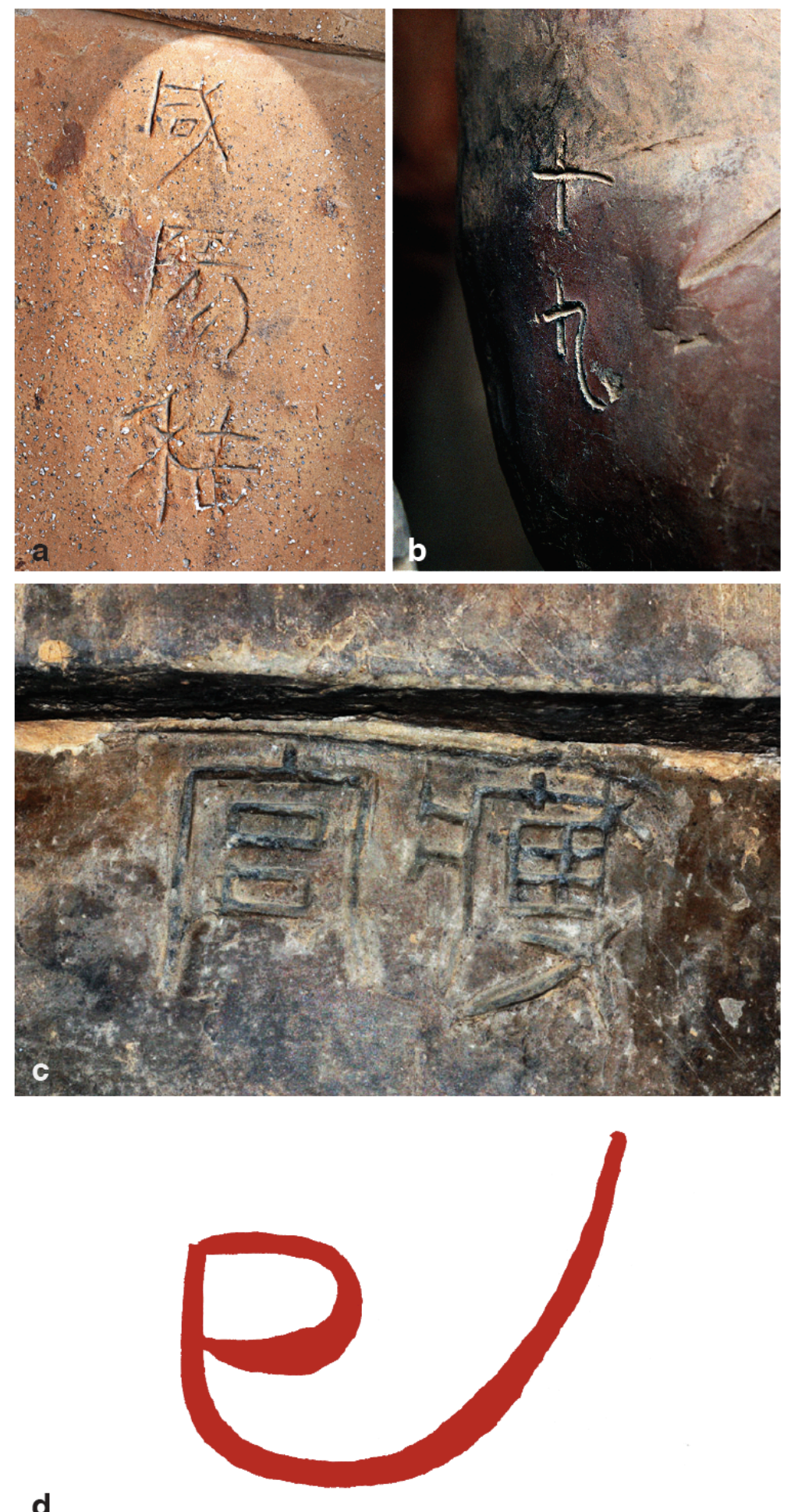

d

2. Marks on the warriors: (a) a stamped mark with Gong (宫) and the personal name Zang (蔵 Appendix 1: code 4), (b) an incised mark with the place-name Xianyiang (咸 阳) and the personal name Jie (秸 Appendix 1: code 14), (c) an incised numeral '19' and (d) a mark painted in red, $S i$ ( 巳 meaning unclear in this context). 


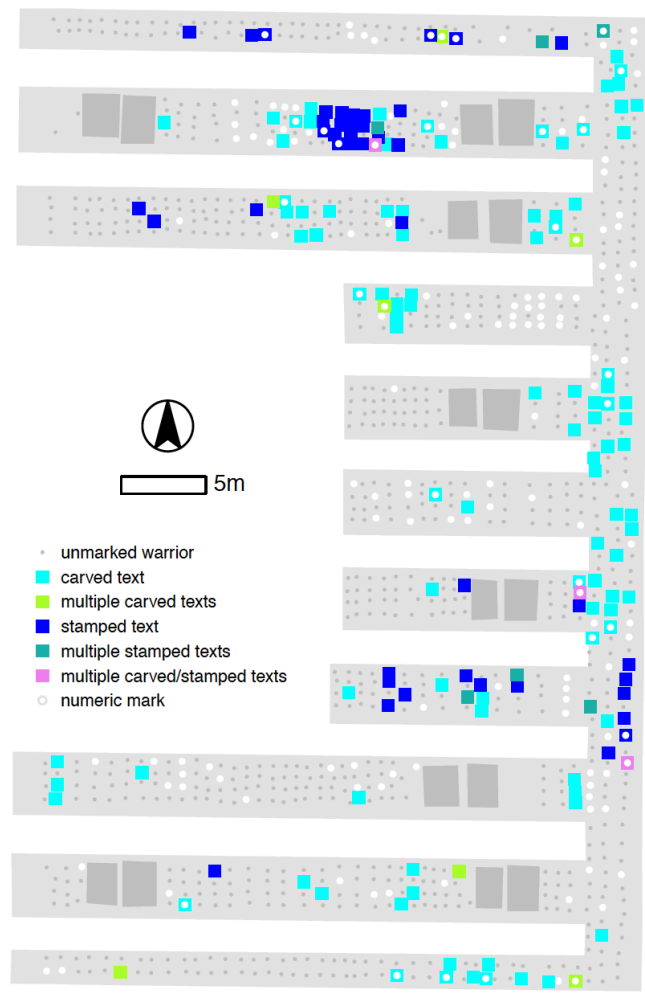

a

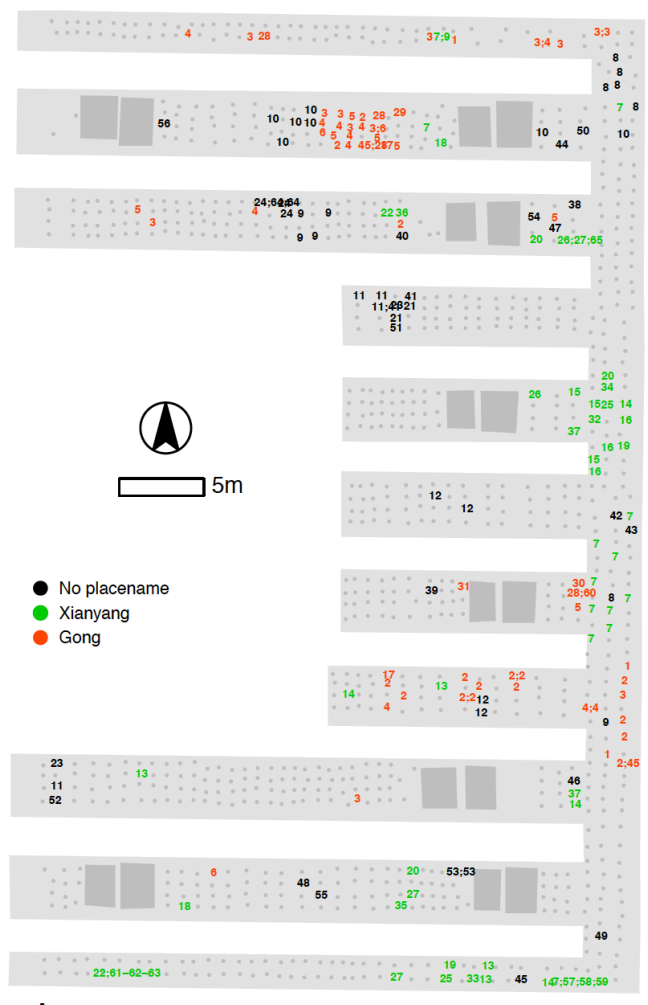

b

3. Spatial patterns of (a) different inscription types and methods on the warriors and (b) different personal names and place-names (for the codes, see Appendix 1) in pit 1 (corridor numbers 1 to 11 are labelled from bottom to top in grey). 

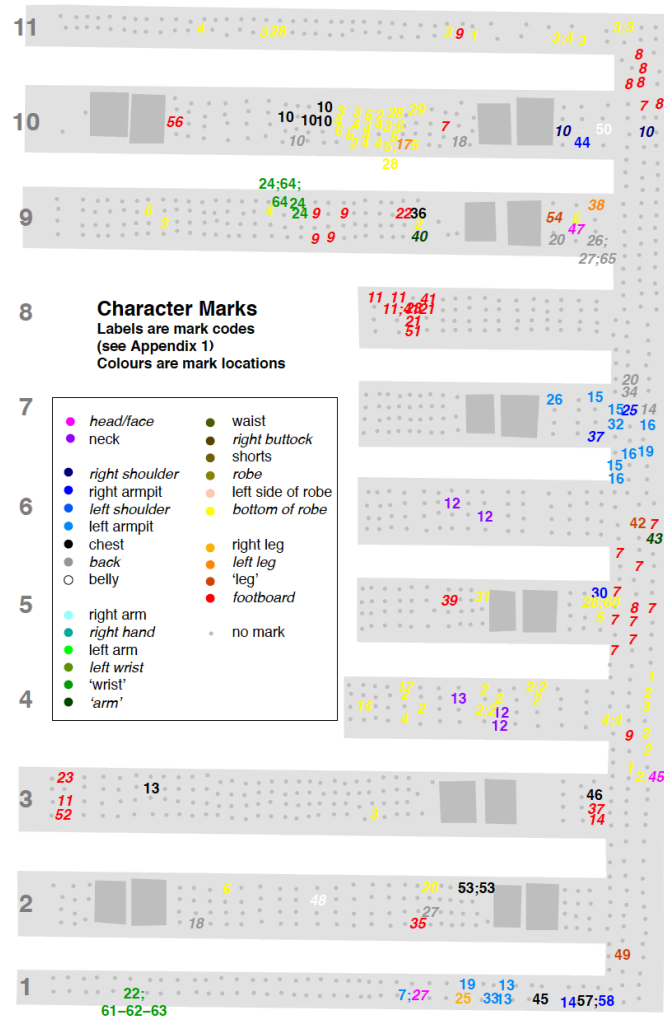

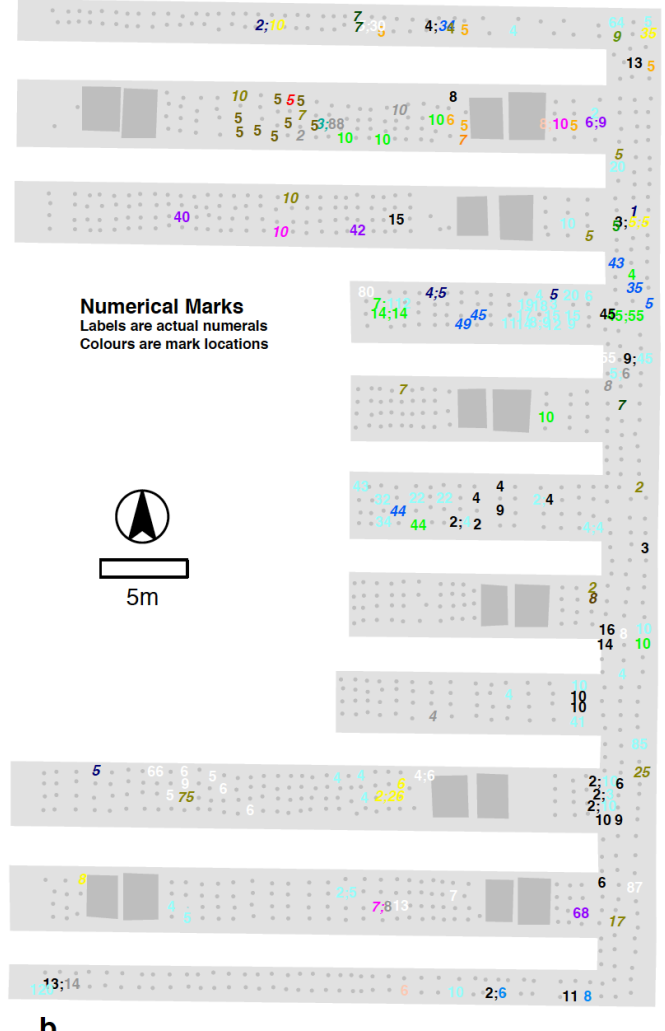

b

4. The position on the warrior bodies of (a) textual and (b) numerical marks (positions are those recorded by the original excavators: labels in quotes are imprecise about the side of the body). 

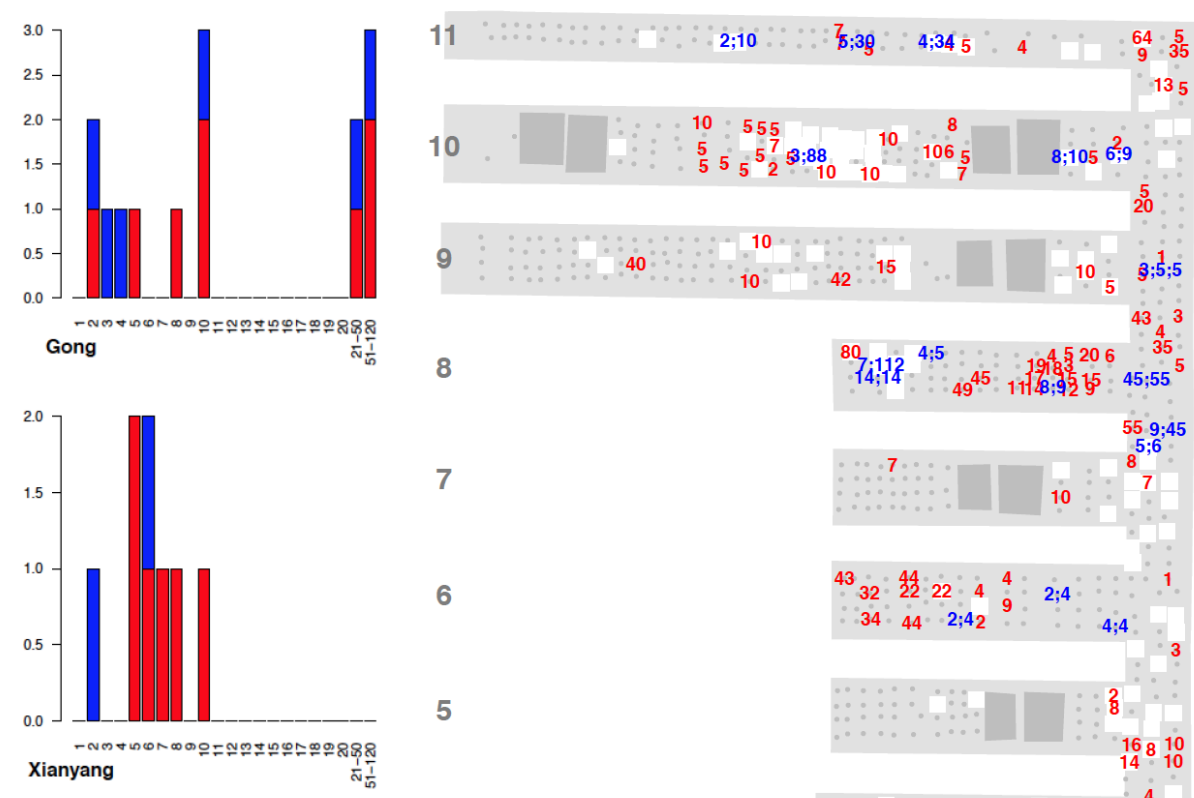

7

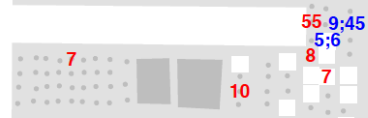

6
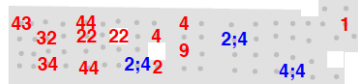

5

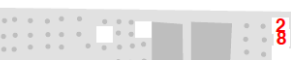

4

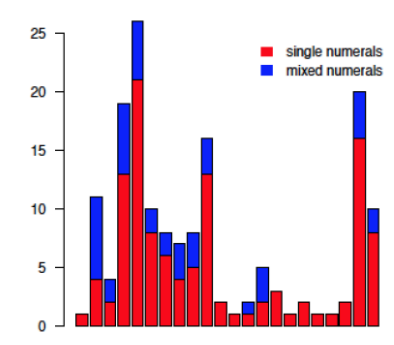

a

No placename

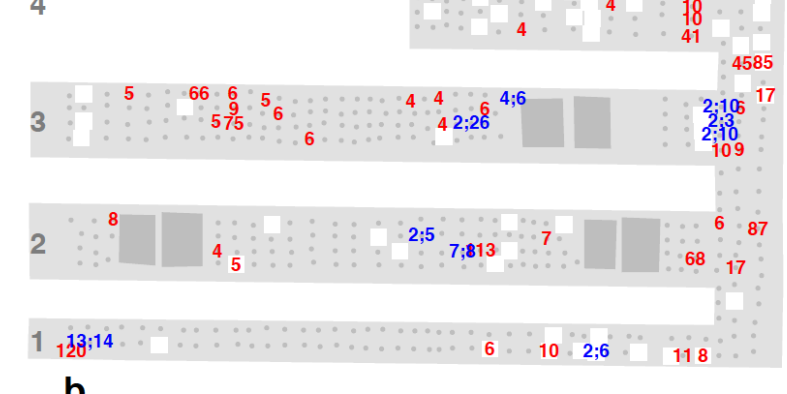

5. (a) Frequency distributions of numerical marks on top of the textual marks, and (b) their locations in pit 1 (in this case, the actual numbers marked on the warriors are shown, rather than codes; corridors numbers shown in grey) 


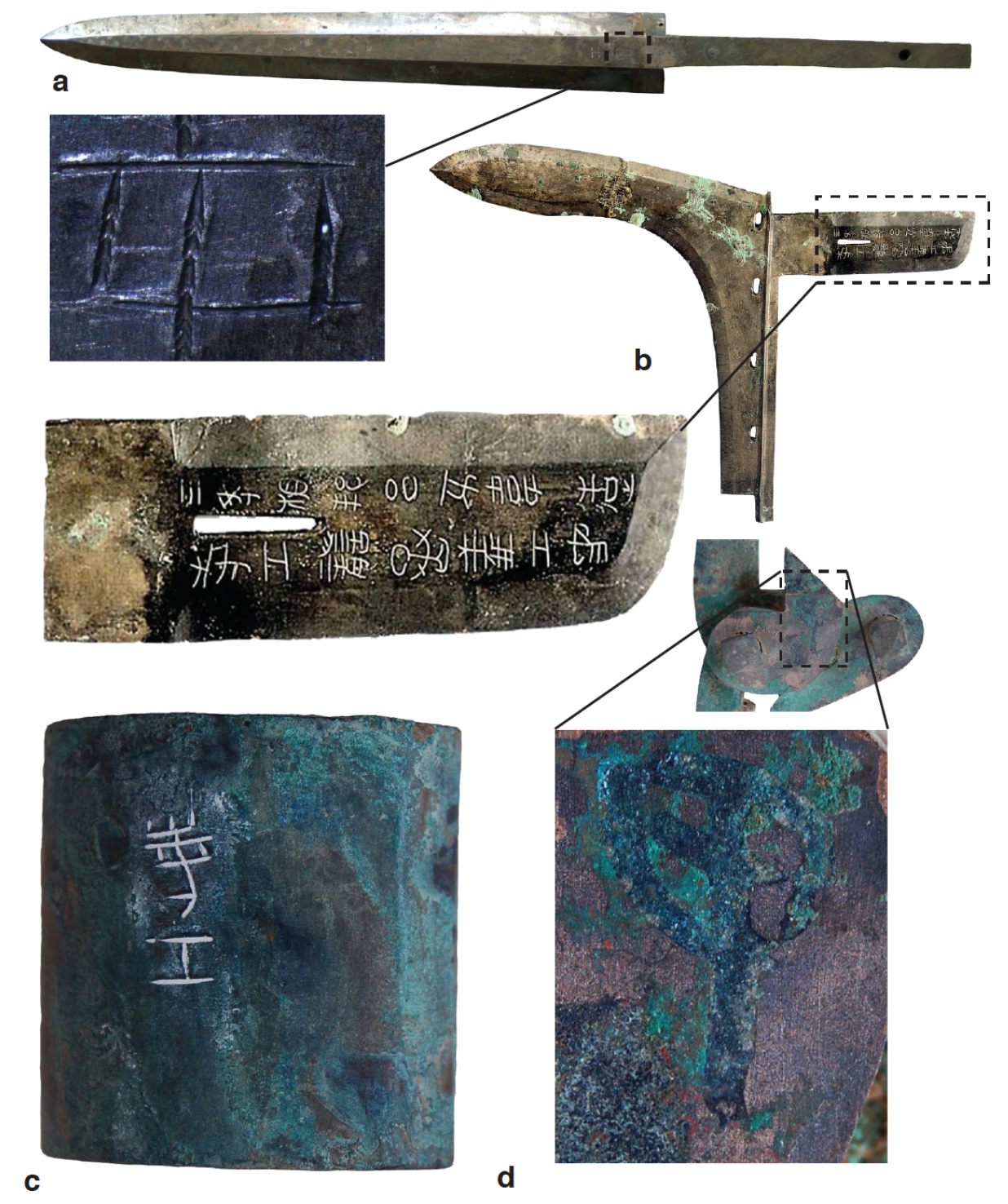

6. Marks on weapons: (a) a long inscription on a dagger axe (T10G6:00577), (b) a chiselled mark on a sword (one of the Sigong characters), (c) an incised mark on a ferrule (Sigong), (d) a painted mark on a crossbow trigger (Via (甲), a stem branch character). 


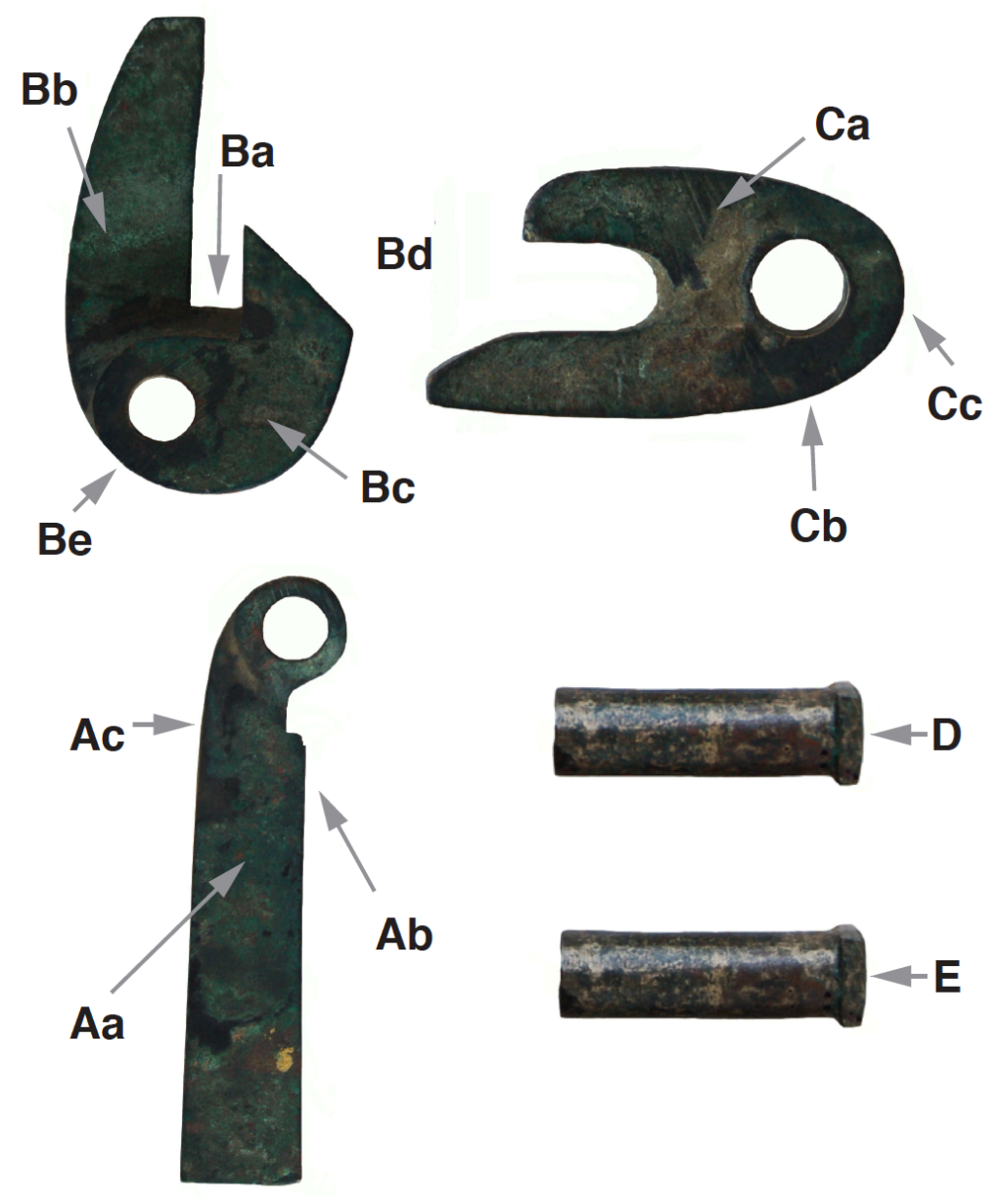

7. Marking locations on crossbow trigger parts A, B, C, D and E. 